Article

\title{
The Effects of Perceived Leader Narcissism on Employee Proactive Behavior: Examining the Moderating Roles of LMX Quality and Leader Identification
}

\author{
Shudi Liao ${ }^{1}{ }^{(0)}$, Beatrice Van der Heijden ${ }^{2,3,4,5,+} \oplus$, Yuhao Liu ${ }^{6, *}$, Xingchi Zhou ${ }^{7, *}$ and \\ Zhiwen Guo ${ }^{1}$ \\ 1 Business School, Hubei University, Wuhan 430062, China; shudiliao@hubu.edu.cn (S.L.); \\ guozhiwen@hubu.edu.cn (Z.G.) \\ 2 Institute for Management Research, Radboud University, 6500 HK Nijmegen, The Netherlands; \\ b.vanderheijden@fm.ru.nl \\ 3 School of Management, Open University of the Netherlands, 6419 AT Heerlen, The Netherlands \\ 4 Department of Marketing, Innovation and Organisation, Ghent University, 9000 Ghent, Belgium \\ 5 Kingston Business School, Kingston University, Kingston upon Thames, London KT2 7LB, UK \\ 6 School of Management, Huazhong University of Science and Technology, Wuhan 430074, China \\ 7 School of Management, Wuhan Textile University, Wuhan 430073, China \\ * Correspondence: yuhao_liu@hust.edu.cn (Y.L.); xczhou@wtu.edu.cn (X.Z.) \\ + Also affiliated with: Business School, Hubei University, Wuhan 430062, China.
}

Received: 31 October 2019; Accepted: 15 November 2019; Published: 22 November 2019

\begin{abstract}
The purpose of this quantitative field study is to examine the relationship between perceived leader narcissism and employee proactive behavior, incorporating leader-member exchange (LMX) quality and leader identification as moderators. Within the social identity theory framework, implicit leadership and social categorization theories are used as the underpinning basis for our hypothesized three-way interaction moderation model. The research sample consisted of 90 groups (including 326 employees and 90 leaders) from different companies in China. Results indicate that there is a three-way interaction effect between perceived leader narcissism, LMX quality, and leader identification, which negatively influences employee proactive behavior. Specifically, when LMX quality and leader identification are both at a high level, the negative relationship between perceived leader narcissism and employee proactive behavior is most salient. Theoretical and practical implications are discussed.
\end{abstract}

Keywords: perceived leader narcissism; LMX quality; leader identification; implicit leadership theories; social categorization theory; employee proactive behavior

\section{Introduction}

Organizations are facing an ever-increasing speed in developments (e.g., new production concepts and new technology) and expanded globalization, herewith urging most employees to constantly monitor their competencies [1,2], and their performance and innovation at the workplace [3-5]. At the contemporary labor market, it is not enough for employees to complete their assigned tasks. Rather, more and more, organizations are expected to align their staff members to leaders that empower their subordinates to display their own initiatives and efforts [6] in order 'to stay in the race' [7]. Otherwise stated, nowadays, working organizations are increasingly dependent on employees portraying an ample amount of proactive behaviors in order to survive in today's dynamic labor market characterized by the growing competition for organizational success [8]. 
Proactive behaviors are characterized as self-starting, goal-oriented, and active behaviors including personal initiative and taking charge [9]. Proactivity at the workplace has flourished in organizational research, over the past 20 years [10], and has shown positive effects regarding both individual-level (e.g., individual performance and job satisfaction [11,12]) and organizational-level outcomes (e.g., organizational performance and success [13,14]).

Leadership behavior is suggested to be an important antecedent for employee proactivity. For example, many studies have found that transformational leadership behavior has a positive relationship with employee proactive behavior [15-17] as well as leader support [18]. The study that is reported in this contribution aims to enhance the scholarly knowledge in this field by investigating the impact of leader narcissism which comprises a personality trait-a cognitive and affective preoccupation with oneself [19]. Narcissism has been described as self-centered, extreme confidence, hard to be persuaded, lack of empathy, and arrogance [20-25]. Despite the fact that narcissism may seem a detrimental phenomenon in working organizations, various studies actually have documented mixed outcomes of the prevalence of narcissism at the workplace [26-29]. In other words, whether narcissism is 'good' or 'bad' has been a contradiction in the literature for decades [30-32].

In addition, empirical work on how leader narcissism affects employee behaviors is scant. We argue that it is of utmost importance to study how this unique personality trait, that is leader narcissism, influences employee proactive behavior, as it does not only contribute to the academic literature but, from a practical point of view, also helps managers to be aware of its possible impact in the reality of organizational practice. Therefore, we propose a contingency model to investigate both the main effect of leader narcissism on employee proactive behavior, as well as the possible three-way interaction effect between leader narcissism, leader identification, and leader-member exchange (LMX) quality. By doing so, we intend to gain more insights into potential mechanisms through which leader narcissism can have an impact on followers' outcomes [33].

This study makes three contributions to the literature. First, we investigate the main effect of perceived leader narcissism on employee proactive behavior. This approach not only contributes to previous work in this scholarly field by responding to the call for more empirical research investigating the role of leader personality or behavior as an antecedent for employee proactive behavior $[5,6,9]$. Yet, by incorporating a dyadic perspective, we are also able to better understand how employees may react to leader narcissism and under which circumstances the effect is more or less detrimental. Second, we propose a moderating role of LMX quality in the relationship between leader narcissism and employees' identification with their leader. According to LMX theory, in case a leader shows more support, i.e., a high-quality relationship exists between the leader and his/her follower, employees, in turn, feel more responsibility to reciprocate with positive work behavior [34]. In low-quality LMX relationships, on the other hand, employees are less likely to take responsibility in this respect $[35,36]$. Last but not least, the third contribution of this study is to explore the added value of a three-way interaction model wherein the LMX quality between employee and his or her leader and employee identification with their leader are included as moderators in the relationship between leader narcissism and employee proactive behavior.

We build upon implicit leadership theories [37] as well as social categorization theories [38] that are used within the social identity framework [39] and propose a recognition-based approach to how employees may react to their leader portraying narcissism by testing a moderation model. According to implicit leadership theories, individuals who label their leaders as having traits such as "dedication, charisma, attractiveness, masculinity, tyranny, and strength" [37] are likely to perceive them as more influential as these leader characteristics are congruent with the role expectations that followers have about their leader [40]. Followers also use their cognitive categories to judge whether a leader is considered to be an effective leader [37]. More specifically, when employees' perceptions about their leader's narcissism do not represent the characteristics (traits, prototypes) that match their expectations about what they believe a leader should be like, the identification of followers with their leader would be weaker. As a result, the amount of proactive behavior they display will be less as well. 
Also, following the line of argumentation from theorizing on the social categorization process [38], perceived LMX quality and leader identification affect the sense of belonging to a group as well as the sense of identity threat or cognitive dissonance, which, in turn, will influence employees' behavior and attitudes [41]. Therefore, to sum up, our hypothesized three-way interaction model examines whether LMX and employee identification with their leader attenuate the assumed negative relationship between employee perceptions of leader narcissism and employee proactive behavior. The following section will go in more depth into the theoretical outline justifying our research hypotheses.

\section{Theoretical Background}

Perceived leader narcissism and employee proactive behavior. In the scholarly literature in this domain, narcissism has been studied as a 'mixed blessing' and a complex trait, and scholars have proposed different effects on possible outcomes over the past decades [31,42]. According to the Diagnostic and Statistical Manual of Mental Disorder, narcissism is described as "grandiose," "fantasies of unlimited success," "hypersensitivity to criticism," "entitlement," "exploitativeness," and "a lack of empathy" [43]. Rosenthal and Pittinsky defined narcissistic leaders as leaders that are "principally motivated by their own egomaniacal needs and beliefs, superseding the needs and interests of the constituents and institutions they lead" [21]. Narcissistic leaders tend to manipulate other people to fulfill their own personal needs and beliefs. Hence, they may, on purpose, be harmful to others, who may, as a result, react with counterproductive work behaviors [44]. Also, narcissistic leaders suffice their need for valuation by triggering self-promotion tactics that often give the impression of being "deceptive, hostile, and intimidating" to others [45,46]. Moreover, narcissistic leaders do not like negative feedback from their employees because they regard them as potential threats, due to superiority-fostering motives [44]. In addition, narcissistic leaders disregard their employees' needs, and rather take the credits and contributions from others [47]. Thus, both by definition and based upon empirical evidence, earlier literature has shown that narcissistic leaders are depicted as inflated, have a lack of consideration for others, and are arrogant figures [20,48].

From the theoretical outline given above, it is clear that in general, researchers have mostly focused on the destructive effects of narcissistic leaders, both theoretically and empirically [49]. However, although narcissism may seem to be a highly destructive phenomenon in an organizational context, numerous scholars have pointed towards the constructive sides of narcissistic leaders. For example, Maccoby suggested that narcissistic leaders may not always be toxic to their organization, and posited that in an age of innovation, narcissistic leaders who have grand visionary are needed in today's chaotic world [27]. Other studies have found that components of narcissism, such as dominance and vision, have positive effects under certain conditions [50,51].

According to implicit leadership theories [37], it is suggested that employees should have a basic cognitive prototype, that is built up through socialization and past experience, in shaping perceptions about their leader [52]. In leader-follower dyadic relationships, employees are likely to rely on the first impression of their leader, which means that employees' perceptions that are congruent with their leader prototype can positively influence the extent to which employees portray desired work-related attitudes and behavior $[53,54]$. We argue that in case employees perceive leader narcissism as potential mistreatment to themselves, their self-starting and future-oriented responses, that is their proactive behaviors or willingness to work for the organization or to solve organizational problems is decreased. Therefore, we hypothesize the following:

Hypothesis 1. Perceived leader narcissism is negatively associated with employee proactive behavior.

The moderating role of LMX. LMX theory $[34,55]$ may be used to explain the moderating role of LMX quality in the relationship between perceived leader narcissism and employees' identification with their leader. According to LMX theory, leader-follower relationships depend on the quality of the exchange [56] and the presence of friendship between a leader and his or her follower [57]. Leaders 
differentiate between members from the in-group (with whom they have a high-quality relationship) versus member from the out-group. In-group members are treated more favorable in comparison with out-group members by their leaders and earlier scholarly work already showed that employees perform better and enjoy higher levels of satisfaction when they have higher-quality LMX relationships with their leaders $[35,36,58]$. We argue that in-group members will also put extra efforts, i.e., display proactive behavior, towards their leader in return. That is to say, reciprocity and mutual benefits are taking shape under the condition of high-quality LMX relationships. Therefore, we expect that the negative effect of perceived leader narcissism will be weakened in the case of high-quality LMX. Based on the outline given above, we hypothesized the following:

Hypothesis 2. LMX moderates the negative relationship between perceived leader narcissism and employee proactive behavior, such that when LMX quality is higher, the negative relationship will be weaker.

The moderating role of identification with one's leader. Identification with one's leader is a construct that is borrowed from the definition of organizational identification [59]. Leader identification refers to an employee's belief about a leader when it comes to self-defining by the employee [60]. The concepts reflect the strength of the psychological relationship linking an employee to his or her leader. According to Pratt's work [59], leader identification has two modes. First, personal identification becomes evident in case employees share similar values with their leader, that is when an individual's belief about a person (in this case a leader) becomes self-referential or self-defining. Second, it becomes evident in case employees want to change their self-concept in order to share similar values and beliefs with their leader. Otherwise stated, employees who have a strong identification with their leader will interpret their leader's goal as their own one, and are willing to strive for their leader's interests and success.

We state that the possible effect of leader narcissism on employee proactive behavior is (partially) moderated by the employee's identification with his or her leader. Moreover, we assume a three-way interaction effect between perceived leader narcissism, LMX, and leader identification. Firstly, implicit leadership theories [37] may be used to explain the so-called recognition-based approach of how identification with one's leader is hypothesized to moderate the relationship between leader narcissism and employee proactive behavior. At the workplace, leaders play an important role because employees' understanding of themselves tends to be influenced by how their leaders treat them [61]. Congruence between employees' perceptions about their leaders and the role expectations they have with regard to their leaders' traits may foster perceived similarity and identification between employees and their leaders [40]. The latter provides a basic understanding between both parties [62]. Basically, employees expect their leaders to align with their prototype of what a leader should be and act like, in particular, "dedication, charisma, attractiveness, masculinity, tyranny, and strength" [37]. Worded differently, because employees possess their own views as to the nature of leaders, their behaviors will change when their attributions and perceptions about their leaders are incongruent.

Secondly, according to social identity theory [39], a sense of belonging to a group is a critical factor that affects an individual's behavior and attitude [63]. We state that LMX and leader identification are two vital components that form the basis for perceptions of belonging to a certain workgroup. Moreover, from a social categorization perspective [38], being one core element of social identity theory [64], scholars suggest that people might face identity threat in the process of social categorization. Social identity threat refers to a negative evaluation drawn by individuals based on which collectives they belong to. Individuals try to maintain a positive perception about their groups. However, under the condition wherein LMX-quality is low or in case employees do not identify with their leader, individuals are more likely to sense social identity threat and will experience negative emotions or will adapt by means of behavior changes that align with group norms [65]. Thus, we argue that, when employees experience high levels of LMX and leader identification, they are expected to feel less identity threat and to behave according to group norms which will reduce their motives of being proactive. 
Last but not least, the interaction between leader narcissism, LMX, and leader identification is worth noticing under the framework of cognitive dissonance theory [66]. When employees' perceptions on LMX quality and identification with their leader are mismatched (one is at a high level while the other one is at a low level), they are likely to experience cognitive dissonance. In order to maintain cognitive consistency, they need to either change their attitude or their behavior. Thus, the three-way interaction between leader narcissism, LMX, and leader identification is expected to influence employees' behavioral outcomes or attitudes.

With regards to the three-way interaction effect, narcissistic leaders naturally will bring stress to those employees that portray risky behavior. After all, the group norm in which a narcissistic leader rules might be more conservative. To some extent, proactive behavior can be considered as risky (e.g., taking charge behavior [67-69]), and therefore we posit that the three-way interaction effect might influence employee proactive behavior negatively. Owen et al. [33] already stressed the need for more empirical work aimed at a better understanding of the inconsistent outcomes of leader narcissism, by focusing on the mechanisms behind its potential effects and by incorporating additional explanatory variables in research models. We argue that the employee's identification with their leader and LMX quality might play an important interactive moderating role in this regard. Concrete, we assume that in a situation wherein employees, perceiving a high-quality LMX with their leaders, identify more strongly with their leader, the destructive effect of narcissism on employee proactive behavior will be strengthened. Oppositely, in case leader identification is less pronounced and LMX quality is low, the psychological linkage between employees and their leader is weakened, herewith decreasing the negative impact of leader narcissism on employee proactive behavior.

Hypothesis 3. The interaction effect between perceived leader narcissism, LMX, and leader identification is negatively related to employee proactive behavior. That is, when LMX and leader identification are at a high level, the negative relationship between perceived leader narcissism and employee proactive behavior is stronger.

\section{Method}

\subsection{Sample and Procedure}

This research has been approved by the ethics board of Huazhong University of Science and Technology, and the study did not involve any human clinical trials or animal experiments. There were no unethical behaviors during the research process and the whole research protocol was in accordance with the recommendations of the research office at Huazhong University of Science and Technology. After having obtained approval, we started to collect data from five enterprises across different industries (including manufacturing, telecommunications, and ICT) in central and southern mainland, China. With the help of human resource (HR) directors in each participating firm, we were able to follow all steps in the procedure outlined below. Firstly, the HR director was asked to randomly select and print out the staff roster of three or more work team members from different organizational units, and to schedule a time for us to conduct the survey. Then, the team leaders and their followers were gathered in different meeting rooms to complete the surveys. We utilized the staff roster to match the leader-follower surveys (every subordinate's survey data will be matched with their leader's survey data in further analysis) throughout the data collection, and we assured full confidentiality. During the data collection process, consent was to be indicated on the first page of our questionnaires, and all participants were informed that this research was only for academic purposes.

In total, data of 337 followers and 92 leaders from different work groups were collected. Two groups with 11 followers and 2 leaders with less than $60 \%$ response rate by their members were excluded from the sample following the criteria suggested by other scholars [70,71]. As a result, the final sample included 326 followers and 90 leaders from 90 work groups. Further, $54.9 \%$ males and $45.1 \%$ females participated, and they had an average age of 28.7 years $(\mathrm{SD}=6.194)$ old, and their tenure in the firm was 3.86 years $(\mathrm{SD}=3.16$ ) on average; $34.1 \%$ of them had a bachelor's degree or higher, $33.4 \%$ 
of them had a college education, and the rest of them had an educational level below high school. The leaders' average tenure in their current position was 4.0 years $(\mathrm{SD}=3.6)$ and their average span of administration was 16.3 followers, ranging from 3 to $65(\mathrm{SD}=15.3)$.

\subsection{Measures}

Perceived leader narcissism. Employees assessed their perception of leaders' narcissism using the six-item scale from Hochwarter and Thompson [46], for which a seven-point Likert-type rating scale was used. A sample item is: "My boss is a very self-centered person" (Cronbach's alpha $=0.825$ ).

Leader identification. Leader identification was reported by employees using the nine-item scale from Shamir et al. [72]. An example item is: "I view the success of a manager as my own success" (Cronbach's alpha $=0.870$ ).

Leader-member exchange (LMX). We adopted the seven-item Likert-type scale from Graen and Uhl-Bien [56] to measure LMX. An example item is: "I have a good working relationship with my leader" (Cronbach's alpha $=0.838$ ).

Employee proactive behavior. Employee proactive behavior was assessed by means of the four-item scale adopted from Belschak and Hartog [15]. Supervisors rated their subordinates' proactive behavior using a scale ranging from 1 to 10 . A sample items is: "He or she realizes his/her personal goals at work" (Cronbach's alpha $=0.873)$.

All the scales adopted in this study had been through the translate and translate-back procedure by professional English-Chinese translators and Professors from management school [73].

Control variables. We controlled for the demographic variables including gender, age, and education level. We also controlled for the length of employment and tenure in the current company. We chose these two variables as control variables because the length of employment and tenure in current company may have great impact on the social exchange process and social identity process between employees and their leaders as well as their organizations. While taken out the time factor, it is better to focus on the influence of leaders.

\section{Results}

We first conducted a series of confirmatory factor analyses (CFA) using Amos 21.0 and maximum likelihood estimates method to ensure that all study constructs were empirically distinct. Next, following Little, Cunningham, Shahar, and Widaman [74], we parceled our constructs due to the small number of teams. Specifically, we parceled leader identification into three items randomly, since the factor loading of each item had a small variance. As indicated in Table 1, the hypothesized four-factor model, with perceived leader narcissism, LMX, leader identification, and proactive behavior, with all items loading on unique factors, produced a better fit in comparison with the alternative models examined, $\mathrm{CMIN}(269)=706.512, p<0.001, \mathrm{RMSEA}=0.071, \mathrm{CFI}=0.885, \mathrm{IFI}=0.886, \mathrm{TLI}=0.872, \mathrm{CMIN} / \mathrm{DF}=2.62$. All items loaded significantly on their respective factors. We also conducted Harman's single factor test and got the cumulative percentage of the first component under $40 \%(29.3 \%)$, which implies our data do not suffer from common method bias very much.

Table 1. Results of confirmatory factor analysis.

\begin{tabular}{|c|c|c|c|c|c|c|c|}
\hline Model & CMIN & DF & RMSEA & CFI & IFI & TLI & CMIN/DF \\
\hline $\begin{array}{c}\text { One factor model: Perceived leader } \\
\text { nar+LMX+Leader identification+Proactive behavior }\end{array}$ & 1907.889 & 275 & 0.135 & 0.572 & 0.574 & 0.533 & 6.93 \\
\hline $\begin{array}{c}\text { Two factor model: Perceived leader } \\
\text { nar+LMX+Leader identification, Proactive behavior }\end{array}$ & 1306.683 & 274 & 0.108 & 0.729 & 0.731 & 0.703 & 4.76 \\
\hline $\begin{array}{l}\text { Three factor model: Perceived leader nar+LMX, } \\
\text { Leader identification, Proactive behavior }\end{array}$ & 1134.526 & 272 & 0.099 & 0.774 & 0.775 & 0.750 & 4.17 \\
\hline $\begin{array}{l}\text { Four factor model: Perceived leader nar, LMX, Leader } \\
\text { identification, Proactive behavior }\end{array}$ & 706.512 & 269 & 0.071 & 0.885 & 0.886 & 0.872 & 2.62 \\
\hline
\end{tabular}

Note. Values in bold indicate the best-fitting model. CMIN: Chi-square; DF: Degree of Freedom; CMIN/DF: Chi-square to DF Ratio; GFI: Goodness of Fit index; NFI: Normed Fit Index; IFI: Incremental Fit Index; TLI: Tucker-Lewis Index; CFI: Comparative Fit Index; RMSEA: Root Mean Square Error of Approximation. 
Table 2 shows the descriptive statistics, inter-correlations, and reliability for all study variables.

Table 2. Descriptive statistics and correlations.

\begin{tabular}{lllllllllll}
\hline Variable & Mean & s.d. & $\mathbf{1}$ & $\mathbf{2}$ & $\mathbf{3}$ & $\mathbf{4}$ & $\mathbf{5}$ & $\mathbf{6}$ & $\mathbf{7}$ & $\mathbf{8}$ \\
\hline 1. Age & 28.8 & 6.162 & 1 & & & & & \\
2. Gender & 1.525 & 1.448 & $-0.269^{* *}$ & 1 & & & & & & \\
3. Education level & 2.04 & 0.858 & $-0.126^{*}$ & -0.012 & 1 & & & & \\
4. Length of employment & 7.025 & 2.831 & $-0.821^{* * *}$ & -0.071 & $-0.238^{* *}$ & 1 & & & & \\
5. Tenure in current company & 3.867 & 3.148 & $-0.663^{* *}$ & -0.062 & -0.064 & $0.718^{* *}$ & 1 & & & \\
6. Perceived leader narcissism & 2.135 & 1.195 & -0.011 & -0.004 & -0.020 & -0.066 & -0.018 & $\alpha=0.825$ & & \\
7. LMX & 5.074 & 1.099 & 0.034 & -0.079 & $0.302^{* *}$ & -0.020 & 0.003 & $-0.262^{* *}$ & $\alpha=0.838$ & \\
8. Leader identification & 5.100 & 1.113 & -0.086 & 0.004 & $0.230^{* *}$ & -0.073 & -0.061 & $-0.274^{* *}$ & $0.695^{* *}$ & $\alpha=0.870$ \\
9. Proactive behavior & 7.846 & 0.986 & -0.030 & -0.003 & 0.020 & 0.010 & $0.120^{*}$ & $-0.135^{*}$ & $0.184^{* *}$ & $0.173^{* *}$ \\
\hline
\end{tabular}

Note. $n=90$ supervisors, 326 employees. Cronbach's alphas appear in parentheses on the diagonal. ${ }^{*} p<0.05 ;{ }^{* *} p<$ $0.01 ; * * * 0.001$

Hierarchical regression analyses have been conducted using SPSS 25.0 to test the research hypotheses. We have followed Cohen, Cohen, West, and Aiken [65] and mean-centered the predictor variables (perceived leader narcissism, LMX, and leader identification) to reduce multi-collinearity and to create the interaction term. The outcomes of the regression analyses are reported in Table 3. The results indicate that perceived leader narcissism is significantly and negatively related to employees' proactive behavior $(b=-0.135, p<0.01)$ (see Step 2 in Table 3), herewith supporting Hypothesis 1.

Table 3. Moderated regression analyses.

\begin{tabular}{|c|c|c|c|c|c|}
\hline \multirow[b]{2}{*}{ Variable } & \multicolumn{5}{|c|}{ Proactive Behavior } \\
\hline & Step 1 & Step 2 & Step 3 & Step 4 & Step 5 \\
\hline \multicolumn{6}{|l|}{ Control Variables } \\
\hline Age & -0.206 & -0.187 & -0.161 & -0.192 & -0.201 \\
\hline Gender & -0.043 & -0.040 & -0.027 & -0.037 & -0.045 \\
\hline Education level & 0.008 & 0.001 & -0.053 & -0.053 & -0.057 \\
\hline Length of Employment & -0.010 & -0.041 & -0.064 & -0.049 & -0.047 \\
\hline Tenure in Current Company & $0.261^{* *}$ & $0.268^{* *}$ & $0.270 * *$ & $0.275^{* *}$ & $0.274^{* *}$ \\
\hline \multicolumn{6}{|l|}{ Predictor } \\
\hline PLN & & $-0.135^{* *}$ & -0.085 & -0.092 & -0.006 \\
\hline \multicolumn{6}{|l|}{ Moderator } \\
\hline LID & & & 0.084 & 0.060 & 0.024 \\
\hline LMX & & & 0.109 & 0.110 & 0.115 \\
\hline \multicolumn{6}{|l|}{ Interaction } \\
\hline $\mathrm{PLN} \times \mathrm{LMX}$ & & & & -0.090 & -0.061 \\
\hline $\mathrm{PLN} \times \mathrm{LID}$ & & & & 0.063 & -0.058 \\
\hline LMX $\times$ LID & & & & -0.048 & -0.058 \\
\hline \multicolumn{6}{|l|}{ 3-way Interaction } \\
\hline $\mathrm{PLN} \times \mathrm{LMX} \times \mathrm{LID}$ & & & & & $-0.205^{* *}$ \\
\hline$\Delta \mathrm{R}^{2}$ & 0.038 & 0.018 & 0.026 & 0.007 & 0.019 \\
\hline $\mathrm{R}^{2}$ & 0.038 & 0.056 & 0.082 & 0.088 & 0.108 \\
\hline Adjusted $\mathrm{R}^{2}$ & 0.023 & 0.038 & 0.059 & 0.057 & 0.074 \\
\hline $\mathrm{F}$ & $2.505 * *$ & $3.128 * * *$ & $3.533 * * *$ & $2.770^{* * *}$ & $3.153^{* * *}$ \\
\hline
\end{tabular}

Note. Standardized beta coefficients are reported. ${ }^{*} p<0.05 ;{ }^{* *} p<0.01 ;{ }^{* * *} p<0.001$; PLN: Perceived Leader Narcissism; LID: Employee Leader Identification; LMX: Leader-Member Exchange.

Next, we adopted the causal steps approach [75] to test the indirect effect. Results suggest that when adding in the moderators (LMX, leader identification) (Step 3), there is no significant relationship between LMX and leader identification, on the one hand, and proactive behavior, on the other hand. Thus, Hypothesis 2 is not supported with our data. In Step 4, we added in the interaction variables and it appeared that the interaction terms did not explain a significant amount of variance in employee proactive behavior. In Step 5, the three-way interaction term was added in the regression analysis, and the results showed that the three-way interaction of perceived leader narcissism, LMX, and 
employee leader identification appeared to have a significant negative effect on employee proactive behavior $(b=-0.205, p<0.01)$. With this outcome, Hypothesis 3 is supported.

Over and above the analytical procedure that has been explained above, we aimed to provide further evidence for our overall hypothesized model. Therefore, and in line with the recommendations by Preacher et al. [76] and Hayes [77], we tried to identify a three-way interaction model using the SPSS macro (PROCESS) on SPSS 25.0 version. The point estimates and 95\% CIs (confidence intervals generated by 5000 bias-corrected bootstrapping sample size) for the conditional indirect effect can be found in Table 4. As can be seen in Table 4, the three-way interaction effect was found with the coefficient of -0.1105 , SE of 0.0424 , and $95 \%$ CI $(-0.1939,-0.0271)$ that does not include zero. The explanatory power of the overall model is $10.78 \%\left(\mathrm{R}^{2}=0.1078, p<0.001\right)$ and the $\mathrm{R}^{2}$ change due to three-way interaction is $0.0194, p<0.01$. As we can see, when leader identification and LMX are high, the three-way interaction effect on employee proactive behaviors is the most saliently negative effect. With this outcome, Hypothesis 3 is confirmed.

Table 4. Moderated regression analyses with bootstrapping by SPSS PROCESS.

\begin{tabular}{|c|c|c|c|c|c|c|}
\hline & & \multicolumn{5}{|c|}{ Proactive Behavior } \\
\hline \multicolumn{2}{|c|}{ Predictor } & \multicolumn{2}{|c|}{$B$} & \multicolumn{2}{|c|}{ SE } & 95\% CI (LL, UL) \\
\hline \multicolumn{2}{|c|}{ PLN } & \multicolumn{2}{|c|}{-0.0061} & \multicolumn{2}{|c|}{0.0653} & $-0.1347,0.1224$ \\
\hline Leader i & ification & \multicolumn{2}{|c|}{0.0245} & \multicolumn{2}{|c|}{0.0795} & $-0.1319,0.1809$ \\
\hline \multicolumn{2}{|c|}{ LMX } & \multicolumn{2}{|c|}{0.1149} & \multicolumn{2}{|c|}{0.0776} & $-0.0377,0.2676$ \\
\hline \multicolumn{7}{|c|}{ Interaction } \\
\hline PLN & & \multicolumn{2}{|c|}{-0.0535} & \multicolumn{2}{|c|}{0.0644} & $-0.1802,0.0731$ \\
\hline PLI & CID & \multicolumn{2}{|c|}{-0.0528} & \multicolumn{2}{|c|}{0.0814} & $-0.2129,0.1074$ \\
\hline $\mathrm{LM}$ & LID & \multicolumn{2}{|c|}{-0.0455} & \multicolumn{2}{|c|}{0.0477} & $-0.1393,0.0483$ \\
\hline \multicolumn{7}{|c|}{ 3-way Interaction } \\
\hline PLN $\times$ & $K \times$ LID & \multicolumn{2}{|c|}{$-0.1105^{* *}$} & \multicolumn{2}{|c|}{0.0424} & $-0.1939,-0.0271$ \\
\hline \multicolumn{7}{|c|}{ Control variables } \\
\hline & & \multicolumn{2}{|c|}{-0.0308} & \multicolumn{2}{|c|}{0.0405} & $-0.1105,0.0489$ \\
\hline & & \multicolumn{2}{|c|}{-0.0326} & \multicolumn{2}{|c|}{0.0172} & $-0.0664,0.0013$ \\
\hline Ed & & \multicolumn{2}{|c|}{-0.0662} & \multicolumn{2}{|c|}{0.0692} & $-0.2023,0.0699$ \\
\hline Length of & ployment & \multicolumn{2}{|c|}{-0.0082} & \multicolumn{2}{|c|}{0.0192} & $-0.0460,0.0296$ \\
\hline Tenure in $\mathrm{Cl}$ & it Company & \multicolumn{2}{|c|}{$0.0659^{* * *}$} & & & $0.0285,0.1033$ \\
\hline & & 0.9 & 0 * & & & $0.0677,1.8043$ \\
\hline $\begin{array}{r}\text { Overall } M \\
\Delta R^{2} \text { due to } 3 \\
\end{array}$ & $\begin{array}{l}\text { Summary } \\
\text { y interaction }\end{array}$ & $\begin{array}{l}\mathrm{R}^{2}=0.107 \\
\triangle \mathrm{R}^{2}=0.01\end{array}$ & $\begin{array}{l}F=3.153, \\
4, F(1, d f 2\end{array}$ & $\begin{array}{l}1=12, \mathrm{df} \\
6.8, \mathrm{df} 2\end{array}$ & $\begin{array}{l}=313, p<0 \\
13, p<0.0\end{array}$ & 001 \\
\hline & Condition & al effect of $X$ & on $\mathrm{Y}$ at val & s of the $\mathrm{m}$ & erator(s): & \\
\hline LMX & LID & Effect & SE & $\mathrm{T}$ & $\mathrm{P}$ & $95 \%$ CI (LL, UL) \\
\hline High & High & -0.2229 & 0.0921 & -2.4218 & 0.0160 & $-0.4041,-0.0418$ \\
\hline & Condit & onal effect $\mathrm{o}$ & $\mathrm{X}^{*} \mathrm{M}$ inter & ion at val & of $W$ : & \\
\hline LID value & Effect & SE & $\mathrm{T}$ & $\mathrm{P}$ & $95 \%$ & CI (LL, UL) \\
\hline-1.0000 & 0.0570 & 0.0822 & 0.6935 & 0.4885 & -0 & $047,0.2187$ \\
\hline 0.0000 & -0.0535 & 0.0644 & -0.8317 & 0.4062 & -0 & $802,0.0731$ \\
\hline 1.0000 & -0.1641 & 0.0716 & -2.2910 & 0.0226 & -0. & $050,-0.0232$ \\
\hline
\end{tabular}

Note. ${ }^{*} p<0.05$; ${ }^{* *} p<0.01$; ${ }^{* * *} p<0.001$. Bootstrap 5000; PLN: Perceived Leader Narcissism; LID: Employee Leader Identification; LMX: Leader-Member Exchange.

Figure 1 visualizes the three-way interaction effect of perceived leader narcissism, LMX, and leader identification on employee proactive behavior. Unstandardized coefficients were used to generate the plotted regression lines [65]. As shown in Figure 1, the expected negative association between perceived leader narcissism and employee proactive behavior is not obvious when employee leader identification and LMX are both low. However, when employee leader identification and LMX are both high, there is a salient negative relationship between perceived leader narcissism and employee 
proactive behavior. Oppositely, a positive relationship between perceived leader narcissism and employee proactive behavior was only found in case the employee leader identification and LMX are not congruent. That is to say, perceived leader narcissism and employee proactive behavior are positively related when leader identification is low and LMX is high, or vice versa.

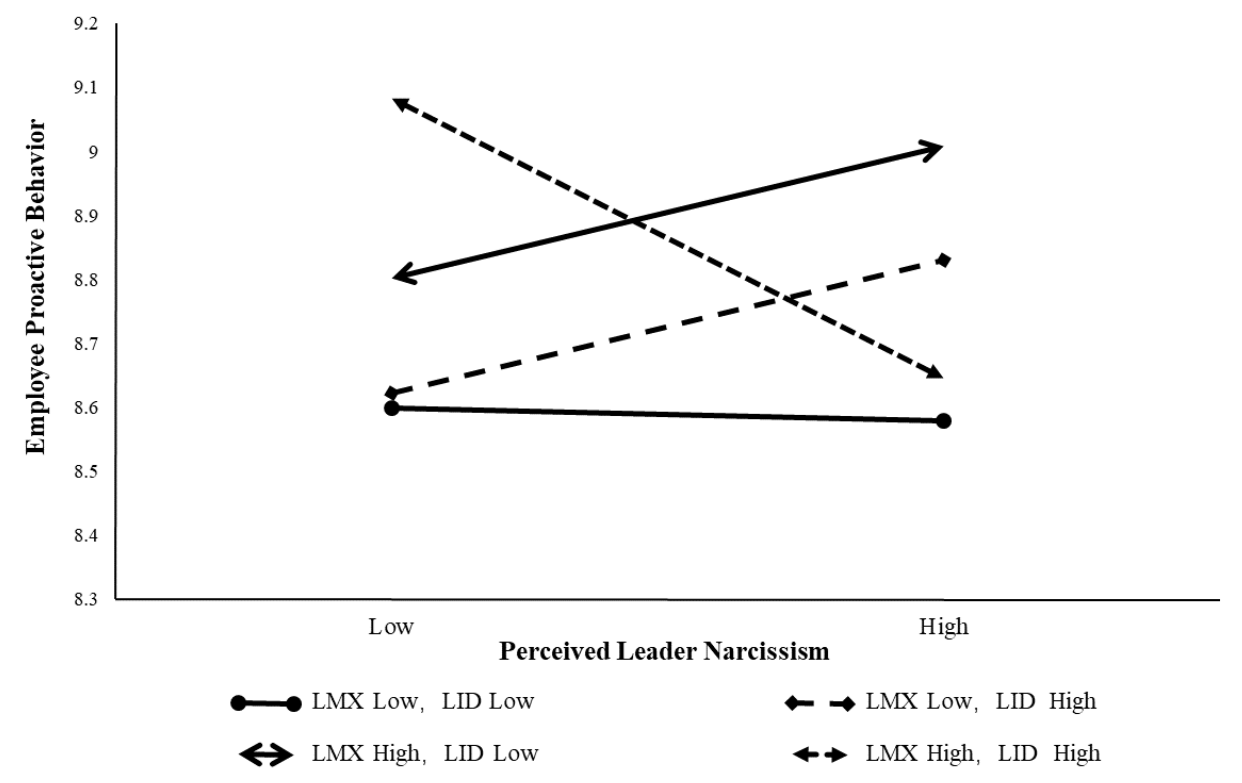

Figure 1. Three-way interaction between perceived leader narcissism, leader-member exchange (LMX), and leader identification. LID: Employee leader identification; LMX: Leader-member exchange.

\section{Discussion}

First, we have found a significantly negative relationship between perceived leader narcissism and employee proactive behavior, which contributes to the personality trait literature. As such, this study responds to the recent call by scholars in this field to further examine antecedents and outcomes of the unique trait of narcissism, and how leader narcissism affects employees' behavior [33]. The empirical study that is reported in this contribution displays the consequence of how employees react on leader narcissism in an organizational context, herewith revealing the possible negative side of narcissism. According to implicit leadership theories [37], due to the value incongruence in the dyadic relationship between leader and subordinate, leader narcissism entails employees' willingness for self-staring and goal-oriented intention minimized. Proactive behavior is a form of discretionary behaviors that individuals may engage in and that go together with self-starting processes that are aimed at obtaining potential benefits for themselves and for their organizations [78]. In this empirical study, we examined whether leader narcissism has a negative effect on employee proactive behavior, and found support for this assumption, herewith contributing to the proactivity literature.

Second, we examined the moderating roles of LMX and leader identification in the relationship between perceived leader narcissism and employees' proactive behavior. Unexpectedly, these interaction effects were not significant. A possible explanation might be the misfit of our theoretical framing with the specific sub hypotheses. In particular, LMX theory states that a leader and their employees are high in reciprocity in case of a high-quality LMX relationship. Even if employees perceive leader narcissism, because of the high LMX quality, it is to be expected that the negative relationship between leader narcissism and employees' proactive behavior might weaken. However, social identity theory [79] suggests that we consider group norm and the process of categorization as important factors that affect individual behavior outcomes. More specifically, a narcissistic leader is likely to be a source of stress and will withhold employees from conducting risky behavior such as proactive behavior (e.g., taking charge, voice, etc.) and will rather bring about that a conservative group norm will be kept up, which will diminish employee proactive behavior. Indeed, further analyses have shown 
that the three-way interaction effect was non-significant in case LMX and leader identification were mismatched. According to cognitive dissonance theory [66], an employee either having a high-quality LMX relationship but with low leader identification or, on the opposite, having high identification with their leader but a low-quality LMX relationship would experience cognitive dissonance. In this case, he/she would change their behavior or attitude in order to get comfortable with this conflicted situation. They may engage in more proactive behavior to gain positive evaluation and information about the group norm.

However, social categorization theory suggests that in such a situation of incongruence, individuals would sense identity threat and as a result, they may deprive themselves of the group and their amount of proactive behavior will decrease. Obviously, it is necessary to gain more in-depth insight into this issue and to study the psychological mechanisms behind this phenomenon more precisely.

Third, using a recognition-based approach, we aimed to better understand the psychological mechanism linking perceived leader narcissism and employee proactive behavior. We built upon implicit leadership theories as well as social identity theory to hypothesize how leader narcissism might interact with LMX and employee's identification with the leader. Congruence in terms of the quality of the exchange relationship (LMX) fosters perceived similarity and identification between employees and leader, which provides a basis for sound understanding between both parties [62]. Employees expect the leader to align with the leader prototype: Referring to what a leader should be like. When employees' perceived leader narcissism does not match the characteristic (trait, prototype) of their leader, as well as their expectation of what they think a leader should be like, the identification with their leader would be weakened. Once the identification with their leader attenuates, they may experience identity threat as well as cognitive dissonance, in particular in case of a high-quality LMX, which entails a mismatch with their lower level of leader identification. When employees experience high-LMX quality and high identification with their leader, their behavior will become more aligned with the group norm and thus become more conservative, especially under the supervision of a narcissistic leader. In this case, the level of employee proactive behavior will be diminished. That is to say, we argue that the three-way interaction effect will negatively influence employee proactive behavior, in particular in case all three factors (i.e., perceived leader narcissism, LMX, and leader identification) are scored at a high level.

Theoretical Implications. As mentioned above, this paper extended the literature of narcissistic leader and employee proactive behavior. By incorporating social identity theory and implicit leadership theories, we proposed a recognition-based approach and built a moderation model to explain how employees may react to their leader portraying narcissism. As we found interesting dynamics between variables, social exchange theory and cognitive dissonance theory are also adopted to deepen our understanding on the results. This study reflects the interaction of social identity process as well as social exchange process and extends the literature of both domains.

Practical Implications. Perceived leader narcissism has been found to negatively affect employee proactive behavior. Therefore, we posit that in order to make an organizational more efficient, and to guarantee that employees portray proactive behavior, top management should be aware of the possible dangers of bringing in narcissistic leaders. Psychometrically reliable and valid selection systems should be adopted and interventional mechanisms should be implemented in working organizations in order to quickly identify and to prevent leaders from showing narcissistic behaviors. Specifically, the HR department should take actions on how to identify narcissistic individuals in the stage of recruitment and selection by using effective measures, such as psychological tests, to conscientiously evaluate whether they are qualified in the positions. In case narcissistic individuals are already functioning in management positions, we advocate that it is wise to spur them to take leadership development programs in order to avoid self-interests behavior that may harm the workplace. Also, they should be trained in interpersonal relationship skills and anger management. 


\section{Conclusions}

The main objective of this study was to examine the relationship between perceived leader narcissism and employee proactive behavior as well as the moderating roles of LMX quality and leader identification. We found that employee's perceived leader narcissism is negatively related to employee proactive behavior. LMX quality and leader identification together play important moderating role on the relationship between perceived leader narcissism and employee proactive behavior. That is, when LMX quality and leader identification are both at high level, the negative relationship between perceived leader narcissism and employee proactive behavior are strengthened. When LMX quality and leader identification are incongruent (one is at high level while the other is at low level), the relationship between perceived leader narcissism and employee proactive behavior become positive (but non-significant), and there is no significant relationship between them while LMX quality and leader identification are both low. Our findings revealed interesting dynamics between perceived leader narcissism, LMX quality, leader identification, and employee proactive behavior, and extended the literature of narcissistic leadership and its influence on employee behaviors.

\section{Limitation and Future Directions}

First, we obtained our data at one point in time. Therefore, more work is needed to gain more insight into the long-term effects of narcissism, and to draw causal inferences.

Second, perceived leader narcissism and leader identification were both rated from the same source, that is the employee. Although the common-method bias is not a major issue in this study [80], future study is encouraged to use multiple data sources. Also, we need to conclude different type of companies (such as small and medium-size enterprises, state-owned enterprises) to ensure the generalizability of our findings.

Third, the measurement of perceived leader narcissism that has been used in this research may be considered as a limitation despite the fact that other scholarly work has also used this scale [46]. As narcissism is a complex personality trait, it is hard to assess this. Future research can use other measurements to test leader narcissism, such as NPI 40, NPI 16 [20].

In addition, it is important to expand this study's framework by looking into mediating mechanisms, alternative moderators, and more specific boundary conditions as well as other deeper theoretical perspectives to explain when and how narcissistic leader affect employee proactive behavior. Also, it is worthwhile to look into specific proactive behaviors (such as taking charge and helping behavior) as possible outcome variables rather than the general measurement of employee proactive behavior that has been used in this study.

Author Contributions: Conceptualization, S.L. and X.Z.; methodology, Y.L. and X.Z.; formal analysis, Y.L.; investigation, S.L.; resources, S.L.; writing—original draft preparation, S.L.; writing—review and editing, B.v.d.H.; project administration, Z.G.; funding acquisition, S.L. and X.Z.

Funding: This work was supported by Young Scientists Fund of the National Natural Science Foundation of China (Grant No. 71802073) and National Natural Science Foundation of China (Grant No.71772057). This work was also supported by Young Scientists Fund of Humanities and social sciences of the Ministry of Education of China (Grant No. 19YJC630236), Henan Province Foundation of Education Department (Grant No.2019ZZJH027), Hubei Center for Studies of Human Capital Development Strategy and Policy and Key Research Base of Humanities and Social Science of Hubei Province.

Conflicts of Interest: The authors declare no conflict of interest.

\section{References}

1. Berntson, E.; Sverke, M.; Marklund, S. Predicting Perceived Employability: Human Capital or Labour Market Opportunities? Econ. Ind. Democr. 2006, 27, 223-244. [CrossRef]

2. Nazar, G.; Van der Heijden, B. Possible selves and identity in relation to career development: Evidence from C hilean male middle-aged managers' career narratives. Int. J. Train. Dev. 2014, 18, 66-77. [CrossRef] 
3. Hartog, D.N.; Belschak, F.D. Personal initiative, commitment and affect at work. J. Occup. Organ. Psychol. 2007, 80, 601-622. [CrossRef]

4. Frese, M.; Fay, D.; Hilburger, T.; Leng, K.; Tag, A. The concept of personal initiative: Operationalization, reliability and validity in two German samples. J. Occup. Organ. Psychol. 1997, 70, 139-161. [CrossRef]

5. Parker, S.K.; Williams, H.M.; Turner, N. Modeling the antecedents of proactive behavior at work. J. Appl. Psychol. 2006, 91, 636-652. [CrossRef]

6. Parker, S. From Passive to Proactive Motivation: The Importance of Flexible Role Orientations and Role Breadth Self-efficacy. Appl. Psychol. 2000, 49, 447-469. [CrossRef]

7. De Vos, A.; Van der Heijden, B.I.J.M. Sustainable careers: Introductory chapter. In Handbook of Research on Sustainable Careers; Edward Elgar Publishing: Cheltenham, UK, 2015; pp. 1-19.

8. Grant, A.M.; Parker, S.; Collins, C. Getting credit for proactive behavior: Supervisor reactions depend on what you value and how you feel. Pers. Psychol. 2009, 62, 31-55. [CrossRef]

9. Crant, J.M. Proactive Behavior in Organizations. J. Manag. 2000, 26, 435-462. [CrossRef]

10. Crant, J.M.; Hu, J.; Jiang, K. Proactive personality: A twenty-year review. In Proactivity at Work; Routledge: Abingdon, UK, 2016; pp. 211-243.

11. Grant, A.M.; Ashford, S.J. The dynamics of proactivity at work. Res. Organ. Behav. 2008, 28, 3-34. [CrossRef]

12. Van Dyne, L.; Lepine, J.A. Helping and Voice Extra-Role Behaviors: Evidence of Construct and Predictive Validity. Acad. Manag. J. 1998, 41, 108-119.

13. Frese, M.; Fay, D. Personal initiative: An active performance concept for work in the 21st century. Res. Organ. Behav. 2001, 23, 133-187. [CrossRef]

14. Koop, S.; De Reu, T.; Frese, M. Entrepreneurial orientation and personal initiative. In Success and Failure of Microbusiness Owners in Africa: A Psychological Approach; Greenwood Publishing Group: Westport, CT, USA, 2000; p. 55.

15. Belschak, F.D.; Hartog, D.N.D. Pro-self, prosocial, and pro-organizational foci of proactive behaviour: Differential antecedents and consequences. J. Occup. Organ. Psychol. 2010, 83, 475-498. [CrossRef]

16. Strauss, K.; Griffin, M.A.; Rafferty, A.E. Proactivity Directed Toward the Team and Organization: The Role of Leadership, Commitment and Role-breadth Self-efficacy. Br. J. Manag. 2009, 20, 279-291. [CrossRef]

17. Wu, C.-H.; Parker, S.K.; Wu, L.-Z.; Lee, C. When and Why People Engage in Different Forms of Proactive Behavior: Interactive Effects of Self-construals and Work Characteristics. Acad. Manag. J. 2018, 61, $293-323$. [CrossRef]

18. Wu, C.-H.; Parker, S.K. The role of leader support in facilitating proactive work behavior: A perspective from attachment theory. J. Manag. 2017, 43, 1025-1049. [CrossRef]

19. Westen, D. The Relations Among Narcissism, Egocentrism, Self-Concept, and Self-Esteem: Experimental, Clinical, and Theoretical Consideratio. Psychoanal. Contemp. Thought 1990, 13, 183-239.

20. Emmons, R.A. Narcissism: Theory and measurement. J. Personal. Soc. Psychol. 1987, 52, 11. [CrossRef]

21. Rosenthal, S.A.; Pittinsky, T.L. Narcissistic leadership. Leadersh. Q. 2006, 17, 617-633. [CrossRef]

22. Leckelt, M.; Küfner, A.C.P.; Nestler, S.; Back, M.D. Behavioral Processes Underlying the Decline of Narcissists' Popularity Over Time. J. Pers. Soc. Psychol. 2015, 109, 856-871. [CrossRef]

23. Zeigler-Hill, V.; Vrabel, J.K.; McCabe, G.A.; Cosby, C.A.; Traeder, C.K.; Hobbs, K.A.; Southard, A.C. Narcissism and the pursuit of status. J. Personal. 2019, 87, 310-327. [CrossRef]

24. Carnevale, J.B.; Huang, L.; Harms, P.D. Leader consultation mitigates the harmful effects of leader narcissism: A belongingness perspective. Organ. Behav. Hum. Decis. Process. 2018, 146, 76-84. [CrossRef]

25. Miller, J.D.; Lynam, D.R.; Hyatt, C.S.; Campbell, W.K. Controversies in narcissism. Ann. Rev. Clin. Psychol. 2017, 13, 291-315. [CrossRef] [PubMed]

26. Chatterjee, A.; Hambrick, D.C. It's All about Me: Narcissistic Chief Executive Officers and Their Effects on Company Strategy and Performance. Adm. Sci. Q. 2007, 52, 351-386. [CrossRef]

27. Maccoby, M. Why people follow the leader: The power of transference. Harv. Bus. Rev. 2004, 82, 76-85. [PubMed]

28. Nevicka, B.; De Hoogh, A.H.; Van Vianen, A.E.; Beersma, B.; McIlwain, D. All I need is a stage to shine: Narcissists' leader emergence and performance. Leadersh. Q. 2011, 22, 910-925. [CrossRef]

29. Nevicka, B.; Van Vianen, A.E.M.; De Hoogh, A.H.B.; Voorn, B.C.M. Narcissistic leaders: An asset or a liability? Leader visibility, follower responses, and group-level absenteeism. J. Appl. Psychol. 2018, 103, 703-723. [CrossRef] [PubMed] 
30. Hogan, R.; Kaiser, R.B. What we know about leadership. Rev. Gen. Psychol. 2005, 9, 169-180. [CrossRef]

31. Grijalva, E.; Harms, P. Narcissism: An Integrative Synthesis and Dominance Complementarity Model. Acad. Manag. Perspect. 2014, 28, 108-127. [CrossRef]

32. Judge, T.A.; Lepine, J.A.; Rich, B.L. Loving yourself abundantly: Relationship of the narcissistic personality to self- and other perceptions of workplace deviance, leadership, and task and contextual performance. J. Appl. Psychol. 2006, 91, 762-776. [CrossRef]

33. Owens, B.P.; Wallace, A.S.; Waldman, D.A.; Walker, A.S. Leader narcissism and follower outcomes: The counterbalancing effect of leader humility. J. Appl. Psychol. 2015, 100, 1203-1213. [CrossRef]

34. Ilies, R.; Nahrgang, J.D.; Morgeson, F.P. Leader-member exchange and citizenship behaviors: A meta-analysis. J. Appl. Psychol. 2007, 92, 269-277. [CrossRef] [PubMed]

35. Graen, G.B.; Liden, R.C.; Hoel, W. Role of leadership in the employee withdrawal process. J. Appl. Psychol. 1982, 67, 868-872. [CrossRef]

36. Scandura, T.A.; Graen, G.B.; Novak, M.A. When managers decide not to decide autocratically: An investigation of leader-member exchange and decision influence. J. Appl. Psychol. 1986, 71, 579-584. [CrossRef]

37. Offermann, L.R.; Kennedy, J.K., Jr.; Wirtz, P.W. Implicit leadership theories: Content, structure, and generalizability. Leadersh. Q. 1994, 5, 43-58. [CrossRef]

38. Leonardelli, G.J.; Toh, S.M. Social Categorization in Intergroup Contexts: Three Kinds of Self-Categorization. Soc. Pers. Psychol. Compass 2015, 9, 69-87. [CrossRef]

39. Abrams, D.E.; Hogg, M.A. Social Identity Theory: Constructive and Critical Advances; Springer-Verlag Publishing: Berlin, Germany, 1990.

40. Kenney, R.A.; Blascovich, J.; Shaver, P.R. Implicit Leadership Theories: Prototypes for New Leaders. Basic Appl. Soc. Psychol. 1994, 15, 409-437. [CrossRef]

41. Kang, D.; Stewart, J.; Kim, H.; Kang, D.-S.; Kang, D. The effects of perceived external prestige, ethical organizational climate, and leader-member exchange (LMX) quality on employees' commitments and their subsequent attitudes. Pers. Rev. 2011, 40, 761-784. [CrossRef]

42. Hartog, D.N.D.; De Hoogh, A.H.B.; Belschak, F.D. Toot Your Own Horn? Leader Narcissism and the Effectiveness of Employee Self-Promotion. J. Manag. 2018. [CrossRef]

43. Association, A.P. Diagnostic and statistical manual of mental disorders. BMC Med. 2013, 17, $133-137$.

44. Penney, L.M.; Spector, P.E. Narcissism and Counterproductive Work Behavior: Do Bigger Egos Mean Bigger Problems? Int. J. Sel. Assess. 2002, 10, 126-134. [CrossRef]

45. Glad, B. Why Tyrants Go Too Far: Malignant Narcissism and Absolute Power. Political Psychol. 2002, $23,1-2$. [CrossRef]

46. Hochwarter, W.A.; Thompson, K.W. Mirror, mirror on my boss's wall: Engaged enactment's moderating role on the relationship between perceived narcissistic supervision and work outcomes. Hum. Relat. 2012, 65, 335-366. [CrossRef]

47. Robins, R.W.; Paulhus, D.L. The character of self-enhancers: Implications for organizations. In Personality psychology in the workplace; American Psychological Association: Washington, DC, USA, 2001; pp. 193-219.

48. Campbell, W.K.; Bonacci, A.M.; Shelton, J.; Exline, J.J.; Bushman, B.J. Psychological Entitlement: Interpersonal Consequences and Validation of a Self-Report Measure. J. Pers. Assess. 2004, 83, 29-45. [CrossRef] [PubMed]

49. Ouimet, G. Dynamics of narcissistic leadership in organizations: Towards an integrated research model. J. Manag. Psychol. 2010, 25, 713-726. [CrossRef]

50. Campbell, W.K.; Campbell, S.M. On the Self-regulatory Dynamics Created by the Peculiar Benefits and Costs of Narcissism: A Contextual Reinforcement Model and Examination of Leadership. Self Identity 2009, 8, 214-232. [CrossRef]

51. Harrison, J.K.; Clough, M.W. Characteristics of "state of the art" leaders: Productive narcissism versus emotional intelligence and Level 5 capabilities. Soc. Sci. J. 2006, 43, 287-292. [CrossRef]

52. Lord, R.G. An information processing approach to social perceptions, leadership and behavioral measurement in organizations. Res. Organ. Behav. 1985, 49, 133-161.

53. Brown, D.J.; Lord, R.G. Leadership and perceiver cognition: Moving beyond first order constructs. In How People Evaluate Others in Organizations; Psychology Press: New York, NY, USA, 2001; pp. 181-202. 
54. Maurer, T.J.; Lord, R.G. An Exploration of Cognitive Demands in Group Interaction as a Moderator of Information Processing Variables in Perceptions of Leadership. J. Appl. Soc. Psychol. 1991, 21, 821-839. [CrossRef]

55. Gerstner, C.R.; Day, D.V. Meta-Analytic review of leader-member exchange theory: Correlates and construct issues. J. Appl. Psychol. 1997, 82, 827-844. [CrossRef]

56. Graen, G.B.; Uhl-Bien, M. Relationship-based approach to leadership: Development of leader-member exchange (LMX) theory of leadership over 25 years: Applying a multi-level multi-domain perspective. Leadersh. Q. 1995, 6, 219-247. [CrossRef]

57. Boyd, N.G.; Taylor, R.R. A developmental approach to the examination of friendship in leader-follower relationships. Leadersh. Q. 1998, 9, 1-25. [CrossRef]

58. Reb, J.; Chaturvedi, S.; Narayanan, J.; Kudesia, R.S. Leader Mindfulness and Employee Performance: A Sequential Mediation Model of LMX Quality, Interpersonal Justice, and Employee Stress. J. Bus. Ethics 2018, 1-19. [CrossRef]

59. Pratt, M. To be or not to be: Central questions in organizational identification. In Identity in Organizations: Developing Theory through Conversations; Whetten, D., Godfrey, P., Eds.; Sage Publications: Thousand Oaks, CA, USA, 1998; pp. 171-207.

60. Kark, R.; Shamir, B.; Chen, G. The two faces of transformational leadership: Empowerment and dependency. J. Appl. Psychol. 2003, 88, 246-255. [CrossRef] [PubMed]

61. McAllister, D.J.; Bigley, G.A. Work Context and the Definition of self: How Organizational Care Influences Organization-Basei Self-Esteem. Acad. Manag. J. 2002, 45, 894-904. [CrossRef]

62. Engle, E.M.; Lord, R.G. Implicit Theories, Self-Schemas, and Leader-Member Exchange. Acad. Manag. J. 1997, 40, 988-1010.

63. Tajfel, H.; Turner, J.C.; Austin, W.G.; Worchel, S. An integrative theory of intergroup conflict. In The Social Psychology of Intergroup Relations; Austin, W.G., Worchel, S., Eds.; Brooks/Cole: Monterey, CA, USA, 1979; pp. 56-65.

64. Hogg, M.A. A Social Identity Theory of Leadership. Pers. Soc. Psychol. Rev. 2001, 5, 184-200. [CrossRef]

65. Cohen, P.; West, S.G.; Aiken, L.S. Applied Multiple Regression/Correlation Analysis for the Behavioral Sciences; Informa UK Limited: London, UK, 2014.

66. Festinger, L. A Theory of Cognitive Dissonance; Stanford University Press: Palo Alto, CA, USA, 1962; Volume 2.

67. Kim, T.-Y.; Liu, Z. Taking charge and employee outcomes: The moderating effect of emotional competence. Int. J. Hum. Res. Manag. 2017, 28, 775-793. [CrossRef]

68. Parker, S.K.; Collins, C.G. Taking stock: Integrating and differentiating multiple proactive behaviors. J. Manag. 2010, 36, 633-662. [CrossRef]

69. Chiaburu, D.S.; Baker, V.L. Extra-role behaviors challenging the status-quo: Validity and antecedents of taking charge behaviors. J. Manag. Psychol. 2006, 21, 620-637. [CrossRef]

70. Roth, P.L.; Vier, C.A.B. Response rates in HRM/OB survey research: Norms and correlates, 1990-1994. J. Manag. 1998, 24, 97-117.

71. Timmerman, T.A. Missing persons in the study of groups. J. Org. Behav. 2005, 26, 21-36. [CrossRef]

72. Shamir, B.; Zakay, E.; Breinin, E.; Popper, M. Correlates of Charismatic Leader Behavior in Military Units: Subordinates' Attitudes, Unit Characteristics, And Superiors' Appraisals of Leader Performance. Acad. Manag. J. 1998, 41, 387-409.

73. Hambleton, R.K. Guidelines for Adapting Educational and Psychological Tests; National Center for Education Statistics: Washington, DC, USA, 1996.

74. Little, T.D.; Cunningham, W.A.; Shahar, G.; Widaman, K.F. To Parcel or Not to Parcel: Exploring the Question, Weighing the Merits. Struct. Equ. Model. A Multidiscip. J. 2002, 9, 151-173. [CrossRef]

75. Baron, R.M.; Kenny, D.A. The moderator-mediator variable distinction in social psychological research: Conceptual, strategic, and statistical considerations. J. Pers. Soc. Psychol. 1986, 51, 1173-1182. [CrossRef]

76. Preacher, K.J.; Rucker, D.D.; Hayes, A.F. Addressing Moderated Mediation Hypotheses: Theory, Methods, and Prescriptions. Multivar. Behav. Res. 2007, 42, 185-227. [CrossRef]

77. Hayes, A.F. Introduction to Mediation, Moderation, and Conditional Process Analysis: A regression-Based Approach; Guilford Publications: New York, NY, USA, 2017.

78. Morrison, E.W. Employee Voice Behavior: Integration and Directions for Future Research. Acad. Manag. Ann. 2011, 5, 373-412. [CrossRef] 
79. Hornsey, M.J. Social Identity Theory and Self-categorization Theory: A Historical Review. Soc. Pers. Psychol. Compass 2008, 2, 204-222. [CrossRef]

80. Podsakoff, P.M.; MacKenzie, S.B.; Lee, J.-Y.; Podsakoff, N.P. Common method biases in behavioral research: A critical review of the literature and recommended remedies. J. Appl. Psychol. 2003, 88, 879-903. [CrossRef] 